\title{
Exogenous fibrolytic enzymes and recombinant bacterial expansins synergistically improve hydrolysis and in vitro digestibility of bermudagrass haylage
}

\author{
A. A. Pech-Cervantes, ${ }^{1}$ I. Muhammad, ${ }^{2}$ I. M. Ogunade,${ }^{1,3}$ Y. Jiang, ${ }^{1}$ D. H. Kim, ${ }^{1}$ C. F. Gonzalez, ${ }^{2}$ \\ T. J. Hackmann, ${ }^{1 *}$ A. S. Oliveira,${ }^{4}$ D. Vyas, ${ }^{1}$ and A. T. Adesogan ${ }^{1} \dagger$ \\ ${ }^{1}$ Department of Animal Sciences, University of Florida, Gainesville 32611 \\ 2Department of Microbiology and Cell Science, Institute of Food and Agricultural Sciences, University of Florida, Gainesville 32603 \\ ${ }^{3}$ Division of Food and Animal Science, Kentucky State University, Frankfort 40601 \\ ${ }^{4}$ Institute of Agriculture and Environmental Sciences, Federal University of Mato Grosso, Campus Sinop, Sinop, MT, Brazil, 78890
}

\section{ABSTRACT}

Four experiments were conducted to examine the effects of a recombinant bacterial expansin-like protein (BsEXLX1) from Bacillus subtilis and a commercial exogenous fibrolytic enzyme (EFE) preparation for ruminants on hydrolysis of pure substrates (cellulose and xylan) and in vitro digestibility of bermudagrass haylage (BMH). Recombinant Escherichia coli BL21 strain was used to express BsEXLX1; the protein was purified using an affinity column. In experiment 1, carboxymethylcellulose, Whatman \#1 filter paper (General Electric, Boston, MA) and oat-spelt xylan substrates were subjected to 4 treatments (1) sodium citrate buffer (control), (2) BsEXLX1 (162 $\mu \mathrm{g} / \mathrm{g}$ of substrate), (3) EFE (2.3 mg/g of substrate), and (4) EFE + BsELX1 in 3 independent runs. Samples were incubated at optimal conditions for both additives $(\mathrm{pH}$ 5 and $50^{\circ} \mathrm{C}$ ) or at ruminal $\left(\mathrm{pH} 6\right.$ and $\left.39^{\circ} \mathrm{C}\right)$ or ambient ( $\mathrm{pH} 6$ and $25^{\circ} \mathrm{C}$ ) conditions for $24 \mathrm{~h}$ and sugar release was measured. In experiment 2 , digestibility in vitro of $\mathrm{BMH}$ was examined after treatment with the following: (1) control (buffer only), (2) BsEXLX1 (162 $\mu \mathrm{g} / \mathrm{g}$ of dry matter), (3) EFE (2.2 mg/g of dry matter), and (4) $\mathrm{EFE}+\mathrm{BsEXLX} 1$ in 3 independent runs at $39^{\circ} \mathrm{C}$ for 24 h. Experiment 3 examined effects of EFE and BsEXLX1 on simulated preingestive hydrolysis and profile of released sugars from $\mathrm{BMH}$ after samples were suspended in deionized water with sodium azide at $25^{\circ} \mathrm{C}$ for $24 \mathrm{~h}$ in 2 independent runs. In experiment 4 , the sequence of the BsEXLX1 purified protein was compared with 447

Received January 19, 2019.

Accepted May 7, 2019.

*Current address: Department of Animal Sciences, University of California, Davis 95616.

†Corresponding author: adesogan@ufl.edu ruminal bacterial genomes to identify similar proteins from the rumen. In experiment 1, compared with EFE alone, EFE and BsEXLX1 synergistically increased sugar release from carboxymethylcellulose and Whatman \#1 filter paper under all simulated conditions; however, hydrolysis of xylan was not improved. In experiment 2, compared with EFE alone, treatment with EFE and BsEXLX1 increased neutral detergent fiber and acid detergent fiber digestibility of bermudagrass haylage (by 5.5 and $15 \%$, respectively) and total volatile fatty acid concentrations, and decreased acetate-propionate ratio. In experiment 3, compared with EFE alone. The EFE and BsEXLX1 synergistically reduced concentrations of neutral detergent fiber and acid detergent fiber and increased release of sugars by $9.3 \%$, particularly cellobiose $(72.5 \%)$. In experiment 4 , a similar sequence to that of BsEXLX1 was identified in Bacillus licheniformis, and similar hypothetical protein sequences were identified in Ruminococcus flavefaciens strains along with different protein structures in E. xylanophilum and Lachnospiraceae. This study showed that an expansinlike protein synergistically increased the hydrolysis of pure cellulose substrates and the hydrolysis and digestibility in vitro of $\mathrm{BMH}$.

Key words: expansin-like protein, Bacillus subtilis, fibrolytic enzyme, bermudagrass

\section{INTRODUCTION}

In the tropics and subtropics, the digestibility of forages used to supply energy and effective fiber to dairy cows is low (Armentano and Pereira, 1997; Hanna and Sollenberger, 2007). Therefore, several studies have investigated if exogenous fibrolytic enzymes (EFE) can be used to increase their digestibility. The results of such studies have been largely inconsistent (Jalilvand et al., 2008; Elghandour et al., 2013; Peters et al., 2015). This is partly because in addition to other factors de- 
scribed in previous literature reviews (Beauchemin et al., 2003; Adesogan et al., 2014; Arriola et al., 2017), the efficacy of EFE is dependent on accessibility to the substrate. Cellulose and hemicellulose (HEM) are highly organized structures in plants; however, the presence of lignin in forage biomass creates lignocellulose, an intricate and recalcitrant network (Zhao et al., 2012), which impedes access to digestible fiber in the cell wall. Previous research showed that enzymatic hydrolysis of lignocellulose into fermentable sugars is inherently difficult because the process is hindered by factors like accessibility as well as porosity, particle size, and limited surface area (Zhao et al., 2012; Liu et al., 2015).

Recent strategies to increase enzyme accessibility to digestible cell wall components in the biofuel industry have focused on using expansins and expansin-like proteins (Kim et al., 2009; Liu et al., 2015). These nonhydrolytic proteins facilitate loosening and hydrolysis of lignocellulose by fibrolytic enzymes (Bunterngsook et al., 2014; Bunterngsook et al., 2015). Thus, synergistic effects of cellulases, hemicellulases, and expansins or expansin-like proteins have been examined to increase hydrolysis of cellulose and HEM for bioethanol production (Kim et al., 2009; Bunterngsook et al., 2014, 2015). Silveira and Skaf (2016) reported that expansin-like protein, BsEXLX1, is a chaotropic agent that can disrupt cellulose chains without detectable hydrolysis. A recent meta-analysis showed that synergistic effects between cellulase and recombinant bacterial expansin-like proteins including BsEXLX1 from Bacillus subtilis, increased degradation of cellulose by over 100\% compared with cellulase alone (Liu et al., 2015). However, no studies have examined if expansin-like proteins can improve the efficacy of EFE at improving fiber hydrolysis and digestion in diets or forages fed to dairy cows and other ruminants. Therefore, the objectives of this study were to examine the effects of a recombinant bacterial expansin-like protein (BsEXLX1) and EFE on hydrolysis of pure cellulose and HEM (experiment 1), simulated preingestive hydrolysis and digestibility in vitro (experiment 2) of bermudagrass haylage (BMH) and simulated preingestive hydrolysis and profile of sugars released (experiment 3) from $\mathrm{BMH}$. An additional objective was to investigate if similar loosenin or expansin-like proteins to BsEXLX1 exist in ruminal bacterial genomes (experiment 4). The hypothesis was that synergistic effects between BsEXLX1 and EFE would increase hydrolysis of cellulose and HEM-based pure substrates and increase simulated pre and post-ingestive hydrolysis and in vitro digestibility of $\mathrm{BMH}$.

\section{MATERIALS AND METHODS}

\section{Substrates and Forage}

The substrates used in experiment 1 were low-viscosity carboxymethylcellulose (CMC; pure cellulose) and oat-spelt xylan (Sigma-Aldrich, St. Louis, MO; polymer of $\beta$-D-xylopyranose) and Whatman paper \#1 filter paper (FP, General Electric, Boston, MA; 100\% cellulose), whereas in experiment 2 and 3, Tifton-85 $\mathrm{BMH}$ (Cynodon dactylon) was used because it is widely used as a digestible fiber and energy source in the diet of dairy cows in the Southeast. Representative samples of $\mathrm{BMH}$ were cored from $500-\mathrm{kg}$ bales, dried at $60^{\circ} \mathrm{C}$ for $48 \mathrm{~h}$, and ground to pass through the 1-mm screen of a Wiley mill (Arthur H. Thomas, Philadelphia, PA). The OM, CP, aNDFom, ADF, ADL, and HEM concentrations (DM basis) of the haylage were 93.2, 15.2, $69.2,36.4,3.4$, and $32.8 \%$, respectively, and the DM concentration was $35 \%$.

\section{Experiment 1a: Protein Purification and Initial Validation of Synergy with Cellulase}

The extraction, cloning, purification, and functional characterization of BsEXLX1 were extensively described in a previous study (Cervantes et al., 2016). Briefly, the forward-5'ttgtatttccagggcatgagtgcatttgt tggtatgg-3' and reverse-5'caagcttcgtcatcattattcagga aactgaacatggcc- $3^{\prime}$ were used to amplify the bacterial expansin gene primers (yoaJ gene; Cosgrove, 2015) using genomic DNA from Bacillus subtilis UD1022. The DNA extraction, isolation, and digestion methods described by Sambrook et al. (1989) were used. Bacterial transformation and protein purification were performed according to Pagliai et al. (2015). Briefly, the amplified DNA fragment (BsEXLX1 gene) was cloned into a p15TV-LIC plasmid and inserted into E. coli BL21Star (Life Technologies, Grand Island, NY). Bacterial cells were grown with shaking in Luria-Bertani medium (LB) at $37^{\circ} \mathrm{C}$ under aerobic conditions with $2.5 \mathrm{mM}$ betaine and $1 \mathrm{M}$ sorbitol $(40 \mathrm{~L})$. Bacterial growth was induced using isopropyl $\beta$-D-1-thiogalactopyranoside at an optical density of $600 \mathrm{~nm}=0.5$ and incubated at $17^{\circ} \mathrm{C}$ overnight. The cells were centrifuged at $7,600 \times g$ $4^{\circ} \mathrm{C}$ for $15 \mathrm{~min}$, and the pellet was suspended in binding buffer $[500 \mathrm{~m} M$ sodium chloride $(\mathrm{NaCl}), 5 \%$ glycerol, $50 \mathrm{~m} M$ Tris $\mathrm{pH} 8.0,5 \mathrm{mM}$ imidazole, and $0.5 \mathrm{mM}$ Tris (2-chloroethyl) phosphate], after which cells were lysed by passing them through a French press (Thermo Fisher Scientific, Waltham, MA). The lysed cells were centrifuged at $14,100 \times g$ for $30 \mathrm{~min}$ at $4^{\circ} \mathrm{C}$, then, the 
cell-free extract was added into a metal chelate affinity-column charged with $\mathrm{Ni}^{2}+$ (Qiagen, Germantown, $\mathrm{MD})$. The eluted proteins were dialyzed, and protein concentration was determined using a protein assay kit (Bio-Rad, Hercules, CA). Protein purity was confirmed using SDS-PAGE gel stained with Coomassie blue.

To confirm the presence and activity of BsEXLX1 and synergy with cellulases, a pilot experiment (1a) was conducted using a commercial purified cellulase from Trichoderma reseei (Sigma-Aldrich). Fresh purified protein BsEXLX1 $(0.4 \mathrm{mg} / \mathrm{g}$ of substrate less than $1 \mathrm{~h}$ after purification) and cellulase $(0.4 \mathrm{mg} / \mathrm{g}$ of substrate) were added to Avicel $(10 \mathrm{mg} / \mathrm{mL}$ of cellulose powder; Sigma-Aldrich) substrate and incubated in citrate buffer under optimal conditions for BsEXLX1 (pH 4 and $50^{\circ} \mathrm{C}$; Kim et al., 2009) for 3 and 12 h. Sugar release was measured using the 3-5-dinitrosalicylic acid (DNS) method according to Miller (1959). This experiment was a necessary step to ensure the activity of the protein before continuing with subsequent experiments.

\section{Experiment 1b: Effect of BsEXLX1 and EFE on Hydrolysis of Cellulose and Hemicellulose- Based Pure Substrates}

A commercial xylanase-rich enzyme (Xylanase Plus, Dyadic International, Jupiter, FL) from a nonrecombinant Trichoderma reesei was used in experiment 1 and 2 (Table 1). This EFE was chosen because it had increased the digestibility of a TMR and milk production by dairy cows in a previous experiment (Romero et al., 2016). Before the experiment, endoglucanase (EC 3.2.1.4, endo- $\beta-1,4$-glucanase) and xylanase (EC 3.2.1.8, endo- $\beta-1,4$-xylanase) activities were quantified using 1\% CMC and 4\% oat-spelt xylan as substrates (Sigma-Aldrich). Activities were measured at $\mathrm{pH} 6$ and $39^{\circ} \mathrm{C}$ to mimic ruminal conditions in dairy cows in the United States. One unit of activity was defined as the amount of enzyme that released $1 \mu \mathrm{mol}$ of reducing sugar per minute. Protein concentration was estimated using a Bio-Rad protein assay (Bradford, 1976) with a BSA standard curve. Endoglucanase and xyalanase activities were estimated using glucose and xylose standard curves, respectively (Wood and Bhat, 1988).

Synergistic effects of BsEXLX1 and EFE were examined with a 24-h enzymatic hydrolysis assay and release of water-soluble carbohydrates was measured using the DNS method (Miller, 1959). The EFE dose used was $2.3 \mathrm{mg} / \mathrm{g}$ of substrate based on a previous study (Romero et al., 2015). The dose of BsEXLX1 was $162 \mu \mathrm{g} / \mathrm{g}$ of substrate, which was calculated using the estimated endoglucanase activity in the EFE to maintain a 1:1 ratio of endoglucanase-BsEXLX1 because previous studies demonstrated that synergistic effects were more effective with low concentrations of expansin-like proteins (Kim et al., 2009; Bunterngsook et al., 2015). Briefly, $20 \mathrm{mg}$ of CMC, $6 \mathrm{mg}$ of FP \#1, and $20 \mathrm{mg}$ of oat-spelt xylan were mixed with $0.1 \mathrm{M}$ citrate-phosphate buffer and incubated with deionized water (control), EFE alone, BsEXLX1 alone, or EFE + BsEXLX1. Filter paper was cut into 6-mm diameter circular discs such that each disc weighed $3 \mathrm{mg}$. Two filter paper discs $(6 \mathrm{mg})$ were placed in each tube as the substrate (Kim et al., 2009). Samples were incubated under ruminal conditions in dairy cows (Beauchemin et al., 2003; Colombatto et al., 2003; pH 6 and $39^{\circ} \mathrm{C}$ ), ambient conditions $\left(\mathrm{pH} 6\right.$ and $25^{\circ} \mathrm{C}$ ) and optimal conditions for EFE and BsEXLX1 (pH 4 and $50^{\circ} \mathrm{C}$; Kim et al., 2009; Liu et al., 2015) in quadruplicate in 3 independent runs in previously autoclaved sterilized 2-mL safe-lock tubes (Eppendorf, Edison, NJ). Protein concentrations in both EFE and BsEXLX1 and reducing sugars in the experiment 1 were estimated using the procedures described previously. Blanks were used in each run to correct for EFE, BsEXLX1, and the substrates.

Table 1. Enzymatic activity ( $\mu \mathrm{mol}$ of sugar released/min per gram of exogenous fibrolytic enzyme; EFE) and protein concentration (mg/g of DM) of EFE preparation

\begin{tabular}{|c|c|c|c|c|c|c|}
\hline Item & Activity $^{1}$ & $25^{\circ} \mathrm{C}$ & $39^{\circ} \mathrm{C}$ & $\begin{array}{c}\text { Protein } \\
\text { concentration }\end{array}$ & Source & Form \\
\hline EFE & $\begin{array}{l}\text { Xylanase }^{2} \\
\text { Endoglucanase }^{3} \\
\text { Exoglucanase }^{3}\end{array}$ & $\begin{array}{r}27,433 \\
1,879 \\
0.5\end{array}$ & $\begin{array}{r}39,940 \\
3,043 \\
1.1\end{array}$ & 2.2 & Trichoderma reseei & Liquid \\
\hline $\operatorname{BsEXLX}^{4}$ & - & - & $-^{1.1}$ & 0.162 & Bacillus subtilis & Liquid \\
\hline
\end{tabular}

${ }^{1}$ One enzyme unit was defined as the amount of enzyme that catalyzed the conversion of $1 \mu$ mol of substrate per minute.

${ }^{2}$ Oat spelt xylan (4\%) was used as the substrate for xylanase activity.

${ }^{3}$ Endoglucanase and exoglucanase activities were measured using 1\% carboxymethyl cellulose as substrate.

${ }^{4}$ The bacterial expansin-like protein (BsEXLX1) dose was estimated to ensure a 1:1 ratio with endoglucanase activity under ruminal conditions $\left(39^{\circ} \mathrm{C}\right.$ and $\left.\mathrm{pH} 6\right)$. 


\section{Experiment 2: Effect of BsEXLX1 and EFE on Simulated Preingestive Hydrolysis and In Vitro Ruminal Digestibility of Bermudagrass Haylage}

Synergistic effects between EFE and BsEXLX1 on $\mathrm{BMH}$ were examined using preingestive hydrolysis (Krueger and Adesogan 2008) and a 24-h in vitro ruminal digestibility assay (Goering and Van Soest, 1970). For preingestive hydrolysis, dried, ground $\mathrm{BMH}(0.5$ g) was treated with $50 \mu \mathrm{L}$ of citrate buffer (control) or the buffer + BsEXLX1 $(162 \mu \mathrm{g} / \mathrm{g}$ of $\mathrm{BMH})$ or the buffer with EFE $(2.3 \mathrm{mg} / \mathrm{g}$ of BMH) or the buffer with a combination of EFE and BsEXLX. Samples were incubated in quadruplicate in 3 independent runs using polypropylene tubes sealed with a rubber stopper containing a one-way gas release valve. The mixtures were incubated at $25^{\circ} \mathrm{C}$ for $1 \mathrm{~h}$ to study the preingestive interaction between the additives and substrate before addition of ruminal inoculum.

For in vitro ruminal digestibility, ruminal fluid was collected from 2 mature nonlactating, nonpregnant cannulated Holstein dairy cows at approximately $3 \mathrm{~h}$ after feeding. The cows were fed bermudagrass hay ad libitum supplemented with soybean meal $(0.95 \mathrm{~kg})$ and corn meal $(0.45 \mathrm{~kg})$ with vitamins and minerals to meet maintenance requirement of the cows based on NRC (2001). The collection procedure was approved by the University of Florida Institutional Animal Research Committee. After collection, ruminal fluid was filtered through 4 layers of cheesecloth, gassed with $\mathrm{CO}_{2}$, and mixed with the buffer (Goering and Van Soest, 1970), and $52 \mathrm{~mL}$ of buffered-ruminal fluid was added to each tube. The suspension was immediately incubated for $24 \mathrm{~h}$ at $39^{\circ} \mathrm{C}$. Blanks were used to correct for effects of substrate, EFE, BsEXLX1, and ruminal fluid in each run.

After $24 \mathrm{~h}$, tubes were placed in ice to stop the fermentation. Tube contents were filtered under gravity using previously dried $\left(60^{\circ} \mathrm{C}\right.$ for $\left.48 \mathrm{~h}\right)$ and weighed 125 mm Whatman \#451 paper (Fisher Scientific, Pittsburgh, PA) in conical funnels. Residue samples were oven-dried at $60^{\circ} \mathrm{C}$ for $48 \mathrm{~h}$ and weighed to estimate digestibility of DM. Dried residues were sequentially analyzed for NDF and ADF (Van Soest et al., 1991; AOAC International, 2000) using an Ankom 200 Fiber Analyzer (Ankom, Macedon, NY) in an assay using amylase but excluding sodium sulfite. The NDF was expressed on an ash-free basis. Hemicellulose was calculated as the difference between NDF and ADF concentrations and in vitro true DM, NDF, HEM, and ADF digestibility were calculated similar to previous experiments (Romero et al., 2015).
The filtrate samples were analyzed for $\mathrm{pH}$ (Accumet XL25 pH meter, Thermo Fisher Scientific) and subsequently acidified with $50 \% \mathrm{H}_{2} \mathrm{SO}_{4}(1 \% \mathrm{vol} / \mathrm{vol})$, and then centrifuged at $8,000 \times g$ for $15 \mathrm{~min}$ at $4^{\circ} \mathrm{C}$. The supernatant was frozen $\left(-20^{\circ} \mathrm{C}\right)$ and analyzed for ammonia by colorimetric $\mathrm{N}$ quantification (Technicon, Tarrytown, NY; Noel and Hambleton, 1976). Volatile fatty acid concentrations (Muck and Dickerson, 1988) were analyzed by HPLC (Hitachi L2400, Tokyo, Japan). Briefly, centrifuged samples were filtered in 1-mL vials and frozen until analysis, the flow rate was 0.7 $\mathrm{mL} / \mathrm{min}$, and column temperature was $35^{\circ} \mathrm{C}$ using a Bio-Rad Aminex HPX-87H column (Bio-Rad; Romero et al., 2015).

\section{Experiment 3: Effect of BsEXLX1 and EFE on Preingestive Hydrolysis of Bermudagrass Haylage and the Profile of Sugars Released}

To estimate synergistic effects of BsEXLX1 and EFE on BMH fiber hydrolysis, experiment 2 was repeated without ruminal fluid addition. Samples were incubated for $24 \mathrm{~h}$ at $25^{\circ} \mathrm{C}$ in 2 runs. Treatments and analytical procedures were identical to those in experiment 2 except that samples were incubated in $50-\mathrm{mL}$ tubes without ruminal fluid and sodium azide $(0.02 \%$ wt/ vol) was added to prevent microbial growth (Krueger and Adesogan, 2008). Blanks were included to correct for effects of EFE and BsEXLX1 and the substrate. After incubation, $30 \mathrm{~mL}$ of deionized water was added to the mixture and the suspension was shaken for $1 \mathrm{~h}$ at $9 \times g$ using a Thermos Forma 420 Incubator Shaker (Thermo Fisher Scientific). Tubes were filtered using a previously dried 125-mm Whatman \# 451 filter paper (Thermo Fisher Scientific) in conical funnels. Residues were dried at $60^{\circ} \mathrm{C}$ for $48 \mathrm{~h}$ and analyzed for losses of DM, NDF, HEM, and ADF and reducing sugars using the DNS method previously described. The NDF was analyzed using amylase without sodium sulfite and expressed on an ash-free basis. Filtrate samples were frozen $\left(-20^{\circ} \mathrm{C}\right)$ for sugar analysis. Thawed samples were analyzed for cellobiose, glucose, and xylose concentrations by HPLC (Hitachi, L2400, Tokyo, Japan) using an HPX-87P column (Bio-Rad) equipped with a refractive index detector. Deionized water was used as the mobile phase following the procedure described by Bach-Knudsen and Li (1991). Briefly, samples were filtered using Sep-Pak c18 columns (Waters, Milford, MA), then sample aliquots were mixed with ethanol in a 1:1 ratio, and samples were incubated at $-20^{\circ} \mathrm{C}$ for 30 min and centrifuged for $20 \mathrm{~min}$. The supernatant was 
removed, and the pellet was gassed for $2 \mathrm{~h}$ at $50^{\circ} \mathrm{C}$ with $\mathrm{N}$ and finally suspended in deionized water.

\section{Experiment 4: Identification of BsEXLX1 Homologs in Ruminal Bacterial Genomes}

The DNA of the ligation product (plasmid) encoding the yoaJ gene for expression of BsEXLX1 in $E$. coli cells was sequenced. The inserted DNA sequence was later translated to an AA sequence using ExPASy software (Gasteiger et al., 2005). The encoded protein BsEXLX1 with ID: WP_003231419, was identified by protein Basic Local Alignment Search Tool (BLAST) using the National Center for Biotechnology Information database and the clusters of orthologous groups for the protein (COG ID) was identified (Tatusov et al., 2000). The BsEXLX1 protein (COG ID: COG4305) was compared with proteins in ruminal bacterial genomes in the Integrated Microbial Genomes system (IMG/M; Tatusov et al., 2000). Briefly, a total 447 rumen bacterial genomes (permanent drafts only) were selected from the literature (Russell, 2002) and listed in IMG/M. Then individual genomes were grouped by family and compared with the BsEXLX1 protein sequence using the BLAST protein tool (Chen et al., 2017). Similarities were reported (Table 6) using the percentage of homology, alignment score ( $E$-value), and AA identities.

\section{Statistical Analysis}

All experiments (except experiment 4) were analyzed as a randomized block design with a 2 (EFE dose) $\times 2$ (BsEXLX1 dose) factorial arrangement plus the combination of both additives. Run was the blocking factor. Data on hydrolysis of crystalline cellulose (experiment 1a) or BMH (experiment 3) into sugars under different (1b, rumen, ambient, and optimum) conditions were analyzed separately in each experiment with the following model:

$$
\mathrm{Y}_{\mathrm{ijk}}=\mu+\mathrm{E}_{\mathrm{i}}+\mathrm{Bs}_{\mathrm{j}}+\mathrm{R}_{\mathrm{k}}+\mathrm{EBs}_{\mathrm{ij}}+\varepsilon_{\mathrm{ijk}},
$$

where $\mathrm{Y}_{\mathrm{ijk}}=$ the response variable, $\mu=$ the general mean, $\mathrm{E}_{\mathrm{i}}=$ the effect of $\mathrm{EFE} \mathrm{i}, \mathrm{Bs}_{\mathrm{j}}=$ the effect of BsEXLX1 $\mathrm{j}, \mathrm{R}_{\mathrm{k}}=$ the effect of run $\mathrm{k}, \mathrm{EBs}_{\mathrm{ij}}=$ the EFE $\times$ BsEXLX1 interaction (ij), and $\varepsilon_{\mathrm{ijk}}=$ the experimental error.

For experiment 2, cow was the experimental unit, and therefore the ruminal fluid from each of 2 cows was used to incubate all treatments in each of 3 runs. The laboratory tubes for the in vitro digestibility assays were considered analytical replicates. Effects of addi- tives on in vitro digestibility and fermentation profiles were analyzed using the following model:

$$
\begin{aligned}
\mathrm{Y}_{\mathrm{ijkl}}=\mu & +\mathrm{E}_{\mathrm{i}}+\mathrm{Bs}_{\mathrm{j}}+\mathrm{R}_{\mathrm{k}}+\mathrm{EBs}_{\mathrm{ij}}+\mathrm{C}_{\mathrm{l}} \\
& +\left(\mathrm{C}_{\mathrm{l}} \times \mathrm{R}_{\mathrm{k}}\right)+\varepsilon_{\mathrm{ijkl}},
\end{aligned}
$$

where $\mu=$ the general mean, $E_{i}=$ the fixed effect of $\mathrm{EFE} \mathrm{i}, \mathrm{Bs}_{\mathrm{j}}=$ the fixed effect of BsEXLX1 $\mathrm{j}, \mathrm{R}_{\mathrm{k}}=$ the random effect of run $\mathrm{k}, \mathrm{EBs}_{\mathrm{ij}}=$ the $\mathrm{EFE} \times \mathrm{BsEXLX} 1$ interaction (ij), $\mathrm{C}_{1}=$ the random effect of cow $\times$ run interaction, and $\varepsilon_{\mathrm{ijkl}}=$ the experimental error.

Data were analyzed using the NLME package (Pinheiro et al., 2009) of $\mathrm{R}$ studio (3.1-131) software. Treatment least squares means were compared using the Tukey test with the LSMEANS package (Lenth, 2016) of $\mathrm{R}$ studio. The normality of residuals was examined and verified using the normal probability plot, Shapiro-Wilk test and by plotting standardized residuals against predicted residuals. Significance was declared at $P \leq 0.05$ and tendencies at $P>0.05 \leq 0.10$.

\section{RESULTS AND DISCUSSION}

\section{Protein Purification and Yield}

Recombinant bacterial expansin-like protein (BsEXLX1) was successfully purified using the E. coli BL21 strain. Bacterial yield was $10.5 \pm 0.5 \mathrm{~g}$ of fresh cells per L of LB. Protein yield was on average $5.4 \mathrm{mg}$ of protein per L of LB (40-L total amount). Previous studies reported an average protein yield of $10 \mathrm{mg}$ per L of LB (Kim et al., 2009; Liu et al., 2015). The low protein yield in the current study was attributed to the presence of inclusion bodies during expression by E. coli (Singh et al., 2015). This low yield occurred due to unknown reasons despite inclusion of betaine and sorbitol in the medium to increase the amount of soluble protein (Oganesyan et al., 2007; Rosano and Ceccarelli, 2014).

Typically, expansins and expansin-like proteins are low-molecular-weight proteins $\sim 25$ to $27 \mathrm{kDa}$ (Yennawar et al., 2006; Kim et al., 2009; Georgelis et al., 2011), and in the current study, the estimated molecular weight of the protein was $\sim 27 \mathrm{kDa}$ based on sequencing and SDS-PAGE data (Figure 1a, see Appendix Table $\mathrm{A} 1)$.

\section{Experiment 1a: Pilot Study Results}

This experiment was conducted to confirm the activity of the BsEXLX1 protein, particularly its ability to synergistically increase cellulose hydrolysis by cellulase. Combining BsEXLX1 and cellulase synergisti- 
A

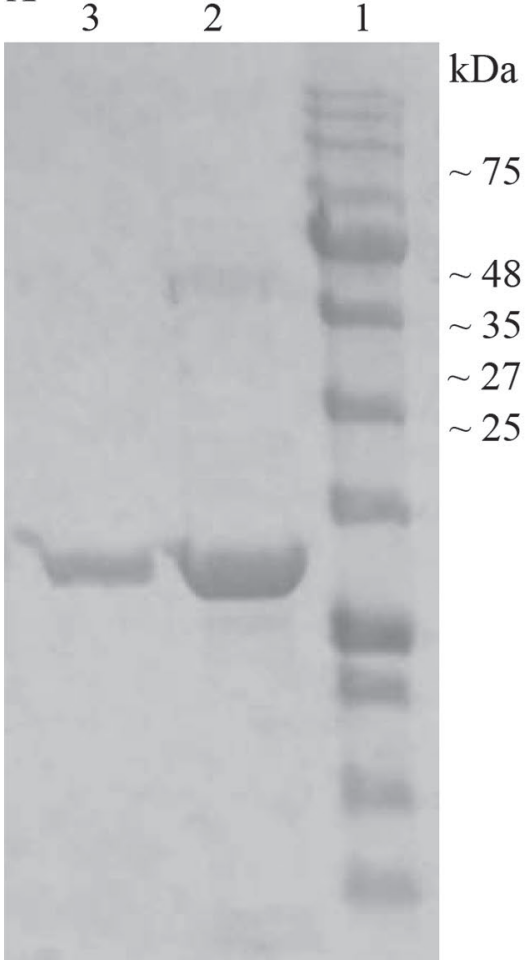

B

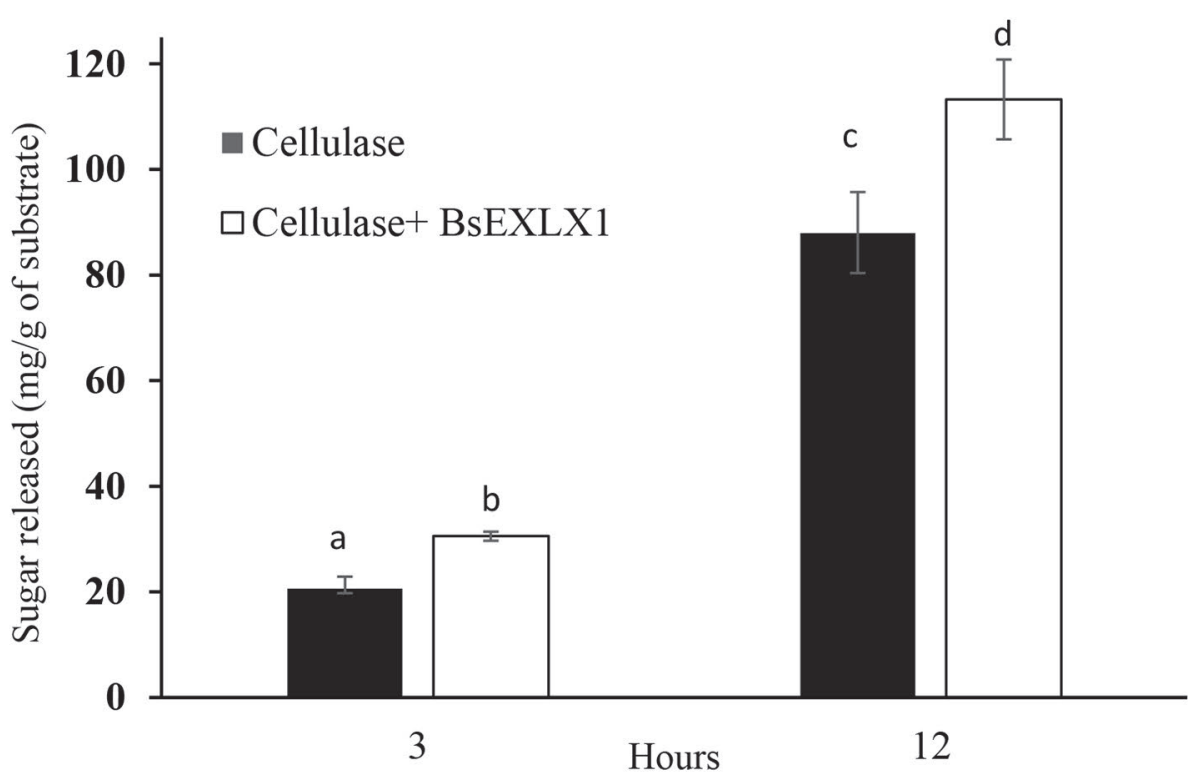

Figure 1. (A) Sodium dodecyl sulfate-PAGE (12\% wt/wt) of the purified recombinant bacterial expansin (BsEXLX1) from Bacillus subtilis Lane 1: molecular ladder, 2: BsEXLX1 protein before dialysis, and 3: BsEXLX1 protein after dialysis. (B) Synergistic effects between freshly purified BsEXLX1 and cellulase on Avicel (Sigma-Aldrich, St. Louis, MO) under optimum conditions for the expansin (pH 4 and $50^{\circ} \mathrm{C}$ ). Error bars indicate SD of the mean. Different letters indicate significant differences $(P<0.05$; pilot study, experiment $1 \mathrm{a}, \mathrm{n}=4)$.

cally increased $(P<0.05)$ reducing sugar release from Avicel compared with cellulase alone by $48.3 \%$ after $3 \mathrm{~h}$ and $28.8 \%$ after $12 \mathrm{~h}$ (Figure $1 \mathrm{~b}$ ). Other studies reported synergistic increases in cellulose hydrolysis when expansins or expansin-like proteins were added to cellulases (Olarte-Lozano et al., 2014; Tovar-Herrera et al., 2015). Recombinant expansins and expansin-like proteins can improve hydrolysis of cellulose because of their high affinity even at low concentrations of cellulose (Georgelis et al., 2011). Previous studies have shown that the cellulase-BsEXLX1 ratio plays a critical role in synergistic effects because BsEXLX1 and cellulase compete for binding sites when both are dosed at high concentrations (Kim et al., 2009; Bunterngsook et al., 2015).

\section{Experiment 1b: Effect of EFE and BsEXLX1 on Cellulose and Hemicellulose Hydrolysis}

Addition of BsEXLX1 and EFE synergistically increased hydrolysis of crystalline (CMC) and insoluble (Whatman filter paper) cellulose $(P<0.01)$ under optimal conditions for the expansin (Kim et al., 2009; Liu et al., 2015) as well as under ruminal and ambient conditions (Table 2). Please see Supplemental Tables S1 and S2 (https://doi.org/10.3168/jds.2019-16339) for main effects of EFE and BsEXLX1, respectively. After $24 \mathrm{~h}$ of incubation, BsEXLX1 synergistically increased $(P<0.01)$ hydrolysis of CMC by EFE by $6.7,8.7$, and $7 \%$ under the respective conditions. Notably, hydrolysis of FP by EFE was synergistically increased $(P<0.01)$ by $33.3 \%$ by BsEXLX1 under ruminal conditions for the additives, suggesting that the synergy was greater for insoluble versus crystalline cellulose. Georgelis et al. (2011) demonstrated that BsEXLX1 has a high binding capacity toward insoluble cellulose because its loosening ability requires a hydrophobic surface to promote electrostatic interactions with fiber (Silveira and Skaf, 2016). This could explain why synergistic effects were remarkably higher in FP compared with CMC.

As expected, hydrolysis of xylan by the EFE was almost 3 times greater than that of cellulose because xylanase activity comprised more than $90 \%$ of the activity of the EFE (Table 1). However, hydrolysis of xylan without EFE was not affected by BsEXLX1 (Table 2), supporting previous findings that synergy between BsEXLX1 and EFE only occurs in cellulose-based substrates (Lin et al., 2013; Liu et al., 2015) and confirm- 
Table 2. Effect of 0 or $162 \mu \mathrm{g} / \mathrm{g}$ of substrate of a recombinant bacterial expansin (BsEXLX1) and exogenous fibrolytic enzyme (EFE) on hydrolysis of cellulose and hemicellulose-based pure substrates under ambient, ruminal, and optimal conditions for the enzyme and expansin (experiment $1 \mathrm{~b}, \mathrm{n}=3$ )

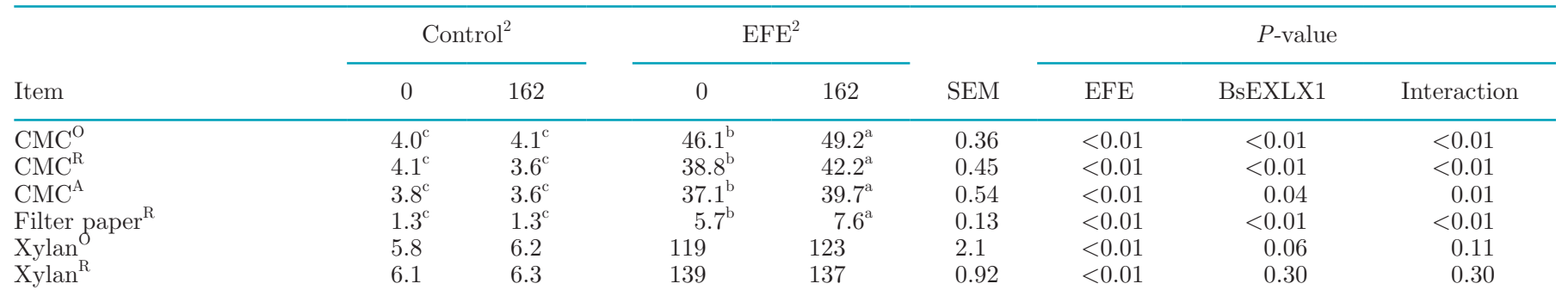

${ }^{\mathrm{a}-\mathrm{c}}$ Different letters in the same row indicate significant differences $(P<0.05)$.

${ }^{1} \mathrm{CMC}=$ carboxymethylcellulose; ${ }^{\mathrm{O}}=$ optimum conditions $\left(\mathrm{pH} 4\right.$ and $\left.50^{\circ} \mathrm{C}\right) .{ }^{\mathrm{R}}=$ rumen conditions $\left(\mathrm{pH} 6\right.$ and $\left.39^{\circ} \mathrm{C}\right) .{ }^{\mathrm{A}}=$ ambient conditions (pH 6 and $25^{\circ} \mathrm{C}$ ).

${ }^{2}$ Sugar released $(\mathrm{mg} / \mathrm{g}$ of substrate).

ing the nonhydrolytic activity of BsEXLX1 (Georgelis et al., 2011; Bunterngsook et al., 2014; Cosgrove, 2015). Furthermore, no synergistic increase in fiber hydrolysis of oat-spelt xylan was evident when BsEXLX1 was added to the EFE. Early studies showed that expansins do not bind xyloglucans and pectins (McQueen-Mason and Cosgrove, 1995). However, recent work has shown that certain bacterial expansin-like proteins bind arabinoxylans (Bunterngsook et al., 2015). Future studies should examine why BsELXLX1 did not synergistically increase hydrolysis of xylan by EFE in the current study.

\section{Experiment 2: Effect of EFE and BsEXLX1 on In Vitro Digestibility and VFA Profiles of Bermudagrass Haylage}

Effects of EFE and BsEXLX1 on in vitro DM digestibility are summarized in Table 3. Adding BsEXLX1 to EFE did not increase DM and HEM digestibility, but compared with the control, BsEXLX1 and EFE synergistically $(P<0.05)$ increased digestibility of $\mathrm{NDF}$ and ADF by 10 and $23.1 \%$, respectively, in BMH (Table 4). Previous studies have reported that EFE can increase digestibility of fiber from various forages and diets (Beauchemin et al., 2003; Phakachoed et al., 2013;
Romero et al., 2015). However, this study provides the first evidence that synergistic effects between fibrolytic enzymes and bacterial expansin-like proteins increased forage fiber digestion. Future research should examine if a similar response occurs in vivo when treated forages or diets are fed to dairy cows.

Adding BsEXLX1 to EFE synergistically increased NDF and ADF digestibility by 5.5 and $15 \%$, respectively, compared with the EFE alone. The NDF fraction includes mainly HEM, cellulose, and lignin, whereas the ADF fraction includes only cellulose and lignin (Van Soest et al., 1991). Synergistic effects between cellulases and BsEXLX1 allow increased hydrolysis of cellulose or lignocellulosic substrates (Kim et al., 2009; Wang et al., 2014; Haque et al., 2015), which could explain why ADF digestibility was increased to a greater extent than NDF digestibility.

Total VFA concentration was synergistically increased by addition of EFE and BsEXLX1 $(P<0.05)$, consequently, $\mathrm{pH}$ was decreased compared with the control (Table 4). Although molar proportions of acetate, butyrate, and isoacids were not affected $(P>0.05)$, that of propionate was synergistically increased $(P<0.05)$ by adding EFE with BsEXLX1 compared with adding EFE alone (19.2 vs. 17.8\%). Fibrolytic enzymes can increase the molar proportion of propionate; however,

Table 3. Effect of addition (0 or $162 \mu \mathrm{g} / \mathrm{g}$ of DM) of a recombinant bacterial expansin like-protein (BsEXLX1) and exogenous fibrolytic enzyme (EFE) on in vitro true dry matter (DMD), neutral detergent fiber (NDFD), hemicellulose (HEMD), and acid detergent fiber (ADFD) digestibility of bermudagrass haylage (experiment $2 ; n=6$ )

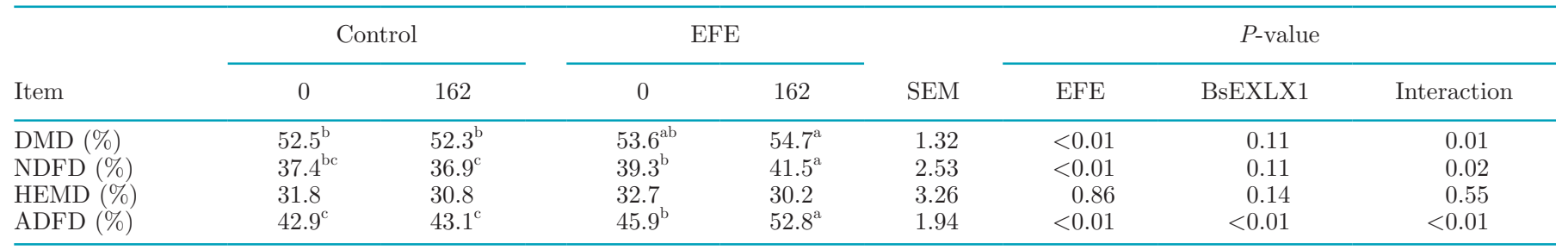

\footnotetext{
${ }^{\mathrm{a}-\mathrm{c}}$ Different letters indicate significant differences $(P<0.05)$.
} 
Table 4. Effect of 0 or $162 \mu \mathrm{g} / \mathrm{g}$ of DM of a recombinant bacterial expansin (BsEXLX1) and exogenous fibrolytic enzyme (EFE) on total VFA and $\mathrm{NH}_{3}-\mathrm{N}$ concentrations, molar proportions of organic acids, and $\mathrm{pH}$ of the filtrate after in vitro fermentation of bermudagrass haylage (experiment $2, \mathrm{n}=6$ )

\begin{tabular}{|c|c|c|c|c|c|c|c|c|}
\hline Item & \multicolumn{2}{|c|}{ Control } & \multicolumn{2}{|c|}{$\mathrm{EFE}$} & SEM & \multicolumn{3}{|c|}{$P$-value } \\
\hline Total VFA (m $M)$ & $64.2^{\mathrm{b}}$ & $60.3^{\mathrm{b}}$ & $67.0^{\mathrm{b}}$ & $79.6^{\mathrm{a}}$ & 3.49 & $<0.01$ & 0.13 & $<0.01$ \\
\hline Propionate (P; \%) & $17.3^{\mathrm{b}}$ & $17.2^{\mathrm{b}}$ & $17.8^{\mathrm{b}}$ & $19.2^{\mathrm{a}}$ & 0.38 & $<0.01$ & 0.01 & $<0.01$ \\
\hline A:P ratio & $3.2^{\mathrm{b}}$ & $3.2^{\mathrm{b}}$ & $3.1^{\mathrm{b}}$ & $2.8^{\mathrm{a}}$ & 0.07 & $<0.01$ & $<0.01$ & 0.01 \\
\hline Butyrate (\%) & 12.9 & 12.8 & 12.6 & 12.3 & 0.33 & 0.16 & 0.46 & 0.64 \\
\hline $\mathrm{NH}_{3}-\mathrm{N}(\mathrm{mg} / \mathrm{dL})$ & 51.3 & 49.4 & 55.3 & 56.1 & 3.55 & $<0.01$ & 0.52 & 0.11 \\
\hline $\mathrm{pH}$ & $7.01^{\mathrm{b}}$ & $6.98^{\mathrm{a}}$ & $6.98^{\mathrm{a}}$ & $6.97^{\mathrm{a}}$ & 0.023 & $<0.01$ & $<0.01$ & 0.04 \\
\hline
\end{tabular}

${ }^{\mathrm{a}, \mathrm{b}}$ Different letters indicate significant differences $(P<0.05)$.

the magnitude of the response depends on the type of enzyme used (Phakachoed et al., 2013; Romero et al., 2015). In the current study, dosing with BsEXLX1 alone decreased (54.1 vs. $55.6 \% ; P=0.01$ ) molar proportion of acetate; however, no effects were observed on $\mathrm{NH}_{3}-\mathrm{N}$ concentration $(P=0.52$; see Experiment 2; see Supplemental Tables S3 and S4, https://doi.org/10.3168/jds .2019-16339, for main effects of EFE and BsEXLX1, respectively). In contrast, compared with other treatments, molar proportion of propionate was increased by adding BsEXLX1 with EFE; consequently, acetate: propionate ratio was synergistically decreased $(P<$ $0.05)$. The latter is likely due to the greater hydrolysis of cellulose into sugars by the additive combination as high sugar concentrations in the rumen shift the ruminal fermentation pattern toward propionate production (France and Dijkstra, 2005).

Romero et al. (2015) reported a marginal increase in $\mathrm{NH}_{3}-\mathrm{N}$ concentrations along with a greater increase in $\mathrm{NDF}$ and $\mathrm{ADF}$ digestibility of $\mathrm{BMH}$ treated with EFE. Similarly, in the current study, addition of EFE increased in vitro digestibility of NDF and ADF as well as $\mathrm{NH}_{3}-\mathrm{N}$ concentrations (see Experiment 2, Supplemental Tables S3 and S4, https://doi.org/10.3168/jds .2019-16339). However, the combination of BsEXLX1 with EFE synergistically increased NDF and ADF digestibility without any changes in $\mathrm{NH}_{3}-\mathrm{N}$ (Table 4). More studies are required to confirm the effects of adding BsEXLX1 with EFE on $\mathrm{NH}_{3}-\mathrm{N}$ concentrations.

\section{Experiment 3: Effect of EFE and BsEXLX1 on Preingestive Hydrolysis of Bermudagrass Haylage and Profile of Released Sugars}

Effects of EFE and BsEXLX1 on preingestive hydrolysis and sugar profiles of BMH are summarized in Table 5. Addition of BsEXLX1 alone did not improve hydrolysis of $\mathrm{BMH}$, further confirming the nonhydrolytic nature of the expansin-like protein; however, adding BsEXLX1 with EFE synergistically increased $(P$ $<0.05$ ), hydrolysis of DM, NDF and ADF by EFE by $5.4,55$, and $128 \%$ compared with EFE alone, supporting the results of experiments $1 \mathrm{a}, 1 \mathrm{~b}$, and 2. Previous studies demonstrated that synergistic effects between

Table 5. Effect of 0 or $162 \mu \mathrm{g} / \mathrm{g}$ of DM of a recombinant bacterial expansin (BsEXLX1) and exogenous fibrolytic enzyme (EFE) on losses of DM, NDF, ADF, and hemicellulose (HEM) and release of reducing sugars, cellobiose, glucose, and xylose after preingestive hydrolysis of bermudagrass haylage (experiment $3, \mathrm{n}=2$ )

\begin{tabular}{|c|c|c|c|c|c|c|c|c|}
\hline Item & \multicolumn{2}{|c|}{ Control } & \multicolumn{2}{|c|}{$\mathrm{EFE}$} & SEM & \multicolumn{3}{|c|}{$P$-value } \\
\hline DM loss (\%) & $18.5^{\mathrm{c}}$ & $18.5^{\mathrm{c}}$ & $20.1^{\mathrm{b}}$ & $21.2^{\mathrm{a}}$ & 0.25 & $<0.01$ & 0.03 & 0.02 \\
\hline HEM loss (\%) & 1.8 & 0.8 & 3.2 & 3.4 & 0.84 & 0.02 & 0.61 & 0.45 \\
\hline ADF loss $(\%)$ & $0.6^{\mathrm{c}}$ & $1.1^{\mathrm{c}}$ & $2.1^{\mathrm{b}}$ & $4.8^{\mathrm{a}}$ & 0.46 & $<0.01$ & $<0.01$ & 0.02 \\
\hline Reducing sugars $(\mathrm{mg} / \mathrm{g}$ of $\mathrm{DM})$ & $76.1^{\mathrm{c}}$ & $65.5^{\mathrm{d}}$ & $108^{\mathrm{b}}$ & $118^{\mathrm{a}}$ & 5.0 & $<0.01$ & 0.91 & $<0.01$ \\
\hline G:X ratio & 0.64 & 0.43 & 1.04 & 1.12 & 0.036 & $<0.01$ & $<0.01$ & 0.07 \\
\hline
\end{tabular}

\footnotetext{
${ }^{\mathrm{a}-\mathrm{d}}$ Different letters in the same row indicate significant differences $(P<0.05)$.
} 
EFE and bacterial expansin-like proteins increased hydrolysis of arabinoxylan and lignocellulolytic substrates by up to 10-fold (Kim et al., 2009; Bunterngsook et al., 2015). Conversely, addition of BsEXLX1 with the EFE did not improve HEM digestibility (experiment 2 ) in the current study, probably because it did not exert synergistic effects on xylanases (experiment 1) and such effects have been only reported with cellulases in most previous studies (Olarte-Lozano et al., 2014; Bunterngsook et al., 2015; Liu et al., 2015).

Reducing sugar concentrations were synergistically increased by adding EFE and BsEXLX1 $(P<0.05)$ by 9.3\% versus EFE alone but adding BsEXLX1 alone had no effect $(P=0.91)$. See Supplemental Tables S5 and S6 (https://doi.org/10.3168/jds.2019-16339) for main effects of EFE and BsEXLX1, respectively. The latter results confirm the nonhydrolytic nature of BsEXLX1 (Georgelis et al., 2014; Liu et al., 2015). Individual sugar analysis revealed that cellobiose concentrations were synergistically increased by $72.5 \%$ by adding EFE and BsEXLX1 $(P<0.05)$ instead of EFE alone. Increases in cellobiose concentrations by EFE and BsEXLX1 suggest that cellobiohydrolases in EFE (Kumar et al., 2008) and BsEXLX1 synergistically cleaved cellulose end-chains to release cellobiose, which can be fermented into organic acids by dominant noncellulolytic ruminal bacteria like Prevotella spp. (Lou et al., 1996).

Adding EFE increased glucose and xylose concentration $(P<0.05)$; however, no interaction effects were observed between BsEXLX1 and EFE on glucose $(P$ $=0.21)$ and xylose concentration $(P=0.68)$. The efficacy of EFE at increasing glucose (by 240\%) and xylose concentration (by $86.2 \%$ ) is in agreement with a previous study (Romero et al., 2015). In contrast, adding BsEXLX1 did not increase glucose concentrations compared with the control $(5.1$ vs. $4.6 \mathrm{mg} / \mathrm{mL} ; P=$ 0.41 ) but increased xylose concentrations (6.1 vs. 4.9 $\mathrm{mg} / \mathrm{mL} ; P=0.02)$. No BsEXLX1 effect was observed on release of reducing sugars compared with control (91.9 vs. $91.7 \mathrm{mg} / \mathrm{g} ; P=0.91$ ). The results observed in the current study with BsEXLX1 are in agreement with previous studies further confirming the nonhydrolytic effect of expansin-like proteins (Georgelis et al., 2011).

Among all cultivars used in the southeast of United States, Tifton 85 has the highest HEM concentration (Bernard et al., 2010), and xyloglucans in HEM typically contains glucose and xylose in an approximate 4:3 ratio (Chen, 2014). In the current study, hydrolysis of HEM was considerably increased by the EFE but not BsEXLX1, and no synergistic increase in concentrations of the individual sugars was evident by combining the additives. Despite the lack of effects of BsEXLX1 on glucose, EFE, and BsEXLX1 tended to increase glucose:xylose ratio $(P=0.07)$. These results imply that synergistic hydrolysis favored release of hexoses from cellulose over pentoses from HEM (Table 5).

\section{Experiment 4: Identification of BsEXLX1 Homologs in Rumen Bacterial Genomes}

Results of examination of alignments between ruminal bacterial genomes and BsEXLX1 are summarized in Table 6. Similar sequences were identified from families Bacillaceace, Ruminococcaceae, Eubacteriaceae, and Lachnospiraceae; however, only 3 bacterial species with similar sequences were found including 2 fiber-digesting bacteria, Ruminococcus flavefaciens and Eubacterium xylanophilum. Several strains of $R$. flavefaciens showed low homology with BsEXLX1 ( $<40 \%)$. However, based on the alignment score and amino acid identities, the ruminal bacterium, Bacillus licheniformis, had a protein with the highest homology $(74.57 \%)$ among all identified species. Previous studies have only found BsEXLX1 in B. subtilis (Kim et al., 2009; Haque et al., 2015); therefore, the fact that a similar sequence of expansinlike protein was found in Bacillus licheniformis in the current study is notable. Both B. licheniformis and B. subtilis have similar chromosomal regions in their genomes (Rey et al., 2004), which explains why a similar protein to BsEXLX1 was found in B. licheniformis. Yet, $B$. subtilis is predominately aerobic, whereas $B$. licheniformis is a facultative anaerobe that, unlike B. subtilis, can grow in special niches in the gastrointestinal tract including the rumen (Rey et al., 2004; Seo et al., 2013). Cellulases and xylanases from B. licheniformis found in native Korean goats increased cellulose hydrolysis (Seo et al., 2013) and feeding B. subtilis and B. licheniformis as probiotics increased milk production and milk fat concentration and yield by sheep (Kritas et al., 2006). Because mature ruminants have few facultative anaerobes (Anderson et al., 1987), future studies should feed B. licheniformis with and without B. subtilis as probiotics to investigate if they improve fiber digestion and milk production by dairy cows.

Some homology with BsEXLX1 was also detected among proteins in R. flavefaciens strains and E. xylanophilum (38.75 and $32.9 \%$ similarity compared with BsEXLX1), which have been described as xylanolytic (Van Gylswyk and Van der Toorn, 1985; Flint et al., 1993). Ruminococcus flavefaciens can produce also endoglucanases as well as hemicellulases (Barros and Thomson, 1987; Shi and Weimer, 1992; Miron et al., 2001). This study showed that many strains of $R$. flavefaciens could produce proteins somewhat similar to BsEXLX1, further analysis is required to evaluate the function of these proteins in rumen bacteria. Future 
Table 6. Alignment of recombinant bacterial expansin like-protein (BsEXLX1) to similar proteins in ruminal bacterial genomes ${ }^{1}$

\begin{tabular}{|c|c|c|c|c|}
\hline Genome $^{2}$ & Homology & $E$-value ${ }^{3}$ & Total AA & AA identities ${ }^{4}$ \\
\hline Bacillus licheniformis VTM3R78 & 74.57 & $2.00 \mathrm{E}-104$ & 232 & 191 \\
\hline Lachnospiraceae bacterium NC2004 & 40 & $5.00 \mathrm{E}-28$ & 422 & 72 \\
\hline R. flavefaciens $\mathrm{Y} 1$ & 39.42 & $5.00 \mathrm{E}-47$ & 295 & 75 \\
\hline R. flavefaciens YL228 & 39.42 & $4.00 \mathrm{E}-47$ & 297 & 74 \\
\hline R. flavefaciens YRD2003 & 39.34 & $1.00 \mathrm{E}-47$ & 289 & 87 \\
\hline R. flavefaciens MA2007 & 39.42 & $4.00 \mathrm{E}-47$ & 297 & 74 \\
\hline R. flavefaciens YAD2003 & 39.15 & $5.00 \mathrm{E}-47$ & 295 & 75 \\
\hline R. flavefaciens 17 & 38.68 & $3.00 \mathrm{E}-45$ & 289 & 75 \\
\hline R. flavefaciens $\mathrm{MC} 2020$ & 38.86 & $6.00 \mathrm{E}-48$ & 289 & 85 \\
\hline R. flavefaciens SAb67 & 38.21 & $1.00 \mathrm{E}-45$ & 293 & 73 \\
\hline Ruminococcus sp. HUN007 & 37.5 & $5.00 \mathrm{E}-42$ & 313 & 81 \\
\hline R. flavefaciens ND2009 & 35.41 & $2.00 \mathrm{E}-33$ & 538 & 75 \\
\hline
\end{tabular}

${ }^{1}$ Bacterial genomes $(\mathrm{n}=447)$ were analyzed by family; similarities were detected based on homology $(\%)$, alignment score $(E$-value), and AA identities; sequences were compared using clusters of orthologous groups for the protein (COG ID): COG4305 (experiment 4).

${ }^{2}$ Bacterial strain named according to the Integrated Microbial Genomes system.

${ }^{3} E$-value is the probability of a having a better or equal alignment during the Basic Local Alignment Search Tool process; the lower the value, the higher the homology (Fassler and Cooper, 2011).

${ }^{4}$ Number of identical AA compared with BsEXLX1 sequence.

studies should investigate if $R$. flavefaciens produces expansin-like proteins and if they synergistically improve hydrolysis and digestion of fiber by the fibrolytic enzymes it produces.

The protein sequences of $R$. flavefaciens strains had a high similarity to Clavi-EXP (see Appendix Table A1), a bacterial expansin-like protein found in Clavibacter michiganesis; however, no synergistic effects were reported after incubating the protein with cellulases for 12 and $24 \mathrm{~h}$ (Georgelis et al., 2014). A 30-kDa noncatalytic cellulose-binding domain (CBD) in $R$. flavefaciens has been detected; however, the function of this $\mathrm{CBD}$ is still not clear (Miron et al., 2001). A more recent study reported the presence of a CBD in $R$. flavefaciens with high affinity toward cellulose and low affinity to xylose (Warner et al., 2013); however, the number of AA is considerably larger than BsEXLX1 (800 vs. 228 residues in BsEXLX1; see Appendix Table A1). Recent data have defined expansin-like proteins as a special type of CBD called CBD family-3a (Orłowski et al., 2018). Thus, future studies should confirm the presence of expansin-like proteins in the $\mathrm{CBD}$ of ruminal bacteria like $R$. flavefaciens.

The sequences found in E. xylanophilum and unidentified Lachnospiraceae NC2004 strains had more (356 and 422 vs. 228) AA than BsEXLX1. These hypothetical proteins were not similar to expansins or expansinlike proteins previously identified (Table 6) based on their $E$-value, AA identities, and relatively low homol- ogy with the BsEXLX1 protein. A recent study demonstrated that bacterial expansin-like proteins can be incorporated into the bacterial cellulosomes (Artzi et al., 2016). These results could explain why AA sequences of E. xylanophilum and species in family Lachnospiraceae (Appendix Table A1) share some sequence similarity with BsEXLX1 despite having far more AA. More studies are required to understand the role of expansins or expansin-like proteins in cellulosomal fiber digestion.

This study showed that adding EFE with BsEXLX1 synergistically increased hydrolyses of pure cellulose but not xylan and increased simulated pre- and postingestive hydrolysis and digestibility in vitro of ADF and NDF of BMH. Future studies should examine if treating forages and dairy cow diets with a combination of EFE and BsEXLX1 synergistically increases the efficacy of $\mathrm{EFE}$ at increasing their digestion, thereby increasing the performance of lactating dairy cows.

\section{CONCLUSIONS}

This study demonstrated that synergistic effects between EFE and a recombinant bacterial expansin (BsEXLX1) increased hydrolysis of cellulose but not xylan. In addition, both additives synergistically increased simulated pre- and postingestive hydrolysis, in vitro digestibility, and rumen-like fermentation of NDF and ADF of BMH. The preingestive hydrolysis assay showed that synergistic effects between EFE and 
BsEXLX1 increased cellobiose concentration by $72 \%$ compared with the EFE alone but did not affect glucose or xylose concentrations. This study also indicated that the ruminal bacterium, B. licheniformis has a similar protein sequence to BsEXLX1 in their genome. More studies are required to examine if adding EFE with BsEXLX1 to forages or ruminant diets increases their hydrolysis and digestion by cows such that milk production is increased. Studies are also needed to confirm the transcription and expression of BsEXLX1 in ruminal bacteria.

\section{ACKNOWLEDGMENTS}

Andres Pech Cervantes thanks the national research council of Mexico (CONACYT) for the scholarship granted to complete his $\mathrm{PhD}$ studies.

\section{REFERENCES}

Adesogan, A. T., Z. X. Ma, J. J. Romero, and K. G. Arriola. 2014. Ruminant nutrition symposium: Improving cell wall digestion and animal performance with fibrolytic enzymes. J. Anim. Sci. 92:1317-1330. https://doi.org/10.2527/jas.2013-7273.

Anderson, K. L., T. G. Nagaraja, J. L. Morrill, T. B. Avery, S. J. Galitzer, and J. E. Boyer. 1987. Ruminal microbial development in conventionally or early-weaned calves. J. Anim. Sci. 64:1215-1226. https://doi.org/10.2527/jas1987.6441215x.

AOAC International. 2000. Official Methods of Analysis. 17th ed. AOAC Int., Arlington, VA.

Armentano, L., and M. Pereira. 1997. Measuring the effectiveness of fiber by animal response trials. J. Dairy Sci. 80:1416-1425. https:/ /doi.org/10.3168/jds.S0022-0302(97)76071-5.

Arriola, K. G., A. S. Oliveira, Z. X. Ma, I. J. Lean, M. C. Giurcanu, and A. T. Adesogan. 2017. A meta-analysis on the effect of dietary application of exogenous fibrolytic enzymes on the performance of dairy cows. J. Dairy Sci. 100:4513-4527. https://doi.org/10.3168/ jds.2016-12103.

Artzi, L., E. Morag, M. Shamshoum, and E. A. Bayer. 2016. Cellulosomal expansin: Functionality and incorporation into the complex. Biotechnol. Biofuels 9:61. https://doi.org/10.1186/s13068 $-016-0474-5$.

Bach-Knudsen, K. E., and B. W. Li. 1991. Determination of oligosaccharides in protein-rich feedstuffs by gas-liquid chromatography and high-performance liquid chromatography. J. Agric. Food Chem. 39:689-694. https://doi.org/10.1021/jf00004a013.

Barros, M. E., and J. A. Thomson. 1987. Cloning and expression in Escherichia coli of a cellulase gene from Ruminococcus flavefaciens. J. Bacteriol. 169:1760-1762. https://doi.org/10.1128/jb.169 .4.1760-1762.1987.

Beauchemin, K. A., D. Colombatto, D. P. Morgavi, and W. Z. Yang. 2003. Use of exogenous fibrolytic enzymes to improve feed utilization by ruminants. J. Anim. Sci. 81:37-47. https://doi.org/10 .2527/2003.8114_suppl_2E37x.

Bernard, J. K., J. J. Castro, N. A. Mullis, A. T. Adesogan, J. W. West, and G. Morantes. 2010. Effect of feeding alfalfa hay or Tifton 85 bermudagrass haylage with or without a cellulase enzyme on performance of Holstein cows. J. Dairy Sci. 93:5280-5285. https://doi .org/10.3168/jds.2010-3111.

Bradford, M. M. 1976. A rapid and sensitive method for the quantitation of microgram quantities of protein utilizing the principle of protein-dye binding. Anal. Biochem. 72:248-254. https://doi.org/ 10.1016/0003-2697(76)90527-3.
Bunterngsook, B., L. Eurwilaichitr, A. Thamchaipenet, and V. Champreda. 2015. Binding characteristics and synergistic effects of bacterial expansins on cellulosic and hemicellulosic substrates. Bioresour. Technol. 176:129-135. https://doi.org/10.1016/j.biortech .2014.11.042.

Bunterngsook, B., W. Mhuantong, V. Champreda, A. Thamchaiphenet, and L. Eurwilaichitr. 2014. Identification of novel bacterial expansins and their synergistic actions on cellulose degradation. Bioresour. Technol. 159:64-71. https://doi.org/10.1016/j.biortech 2014.02.004.

Cervantes, A. A. P., I. Muhammad, C. F. Gonzalez, D. Vyas, and A. T. Adesogan. 2016. Expression and purification of a novel bacterial expansin from Bacillus subtilis that synergistically degrades cellulose with fibrolytic enzymes. J. Anim. Sci. 94(supp. 5). https: //doi.org/10.2527/jam2016-1625.

Chen, H. 2014. Chemical composition and structure of natural lignocellulose. Pages 25-71 in Biotechnology of Lignocellulose. Springer, the Netherlands.

Chen, I. A., V. M. Markowitz, K. Chu, K. Palaniappan, E. Szeto, M. Pillay, A. Ratner, J. Huang, E. Andersen, M. Huntemann, M. Hadjithomas, K. Tennensen, T. Nielsen, N. Ivanova, and N. Kyrpides. 2017. IMG/M: Integrated genome and metagenome comparative data analysis system. Nucleic Acids Res. 45:D507-D516. https://doi.org/10.1093/nar/gkw929.

Colombatto, D., F. L. Mould, M. K. Bhat, and E. Owen. 2003. Use of fibrolytic enzymes to improve the nutritive value of ruminant diets A biochemical and in vitro rumen degradation assessment. Anim. Feed Sci. Technol. 107:201-209. https://doi.org/10.1016/ S0377-8401(03)00126-3.

Cosgrove, D. J. 2015. Plant expansins: Diversity and interactions with plant cell walls. Curr. Opin. Plant Biol. 25:162-172. https://doi .org/10.1016/j.pbi.2015.05.014.

Elghandour, M. M. Y., A. Z. M. Salem, M. Gonzalez-Ronquillo, J. L. Bórquez, H. M. Gado, N. E. Odongo, and C. G. Peñuelas. 2013. Effects of exogenous enzymes on in vitro gas production kinetics and ruminal fermentation of four fibrous feeds. Anim. Feed Sci. Technol. 179:46-53. https://doi.org/10.1016/j.anifeedsci.2012.11 .010 .

Fassler, J., and P. Cooper. 2011 Jul 14. BLAST Glossary from NCBI bookshelf. In: BLAST ${ }^{\circledR}$ Help [Internet]. https://www.ncbi.nlm.nih .gov/books/NBK62051/.

Flint, H. J., J. Martin, C. A. McPherson, A. S. Daniel, and J. X. Zhang. 1993. A bifunctional enzyme, with separate xylanase and beta $(1,3-1,4)$-glucanase domains, encoded by the xynD gene of Ruminococcus flavefaciens. J. Bacteriol. 175:2943-2951. https:// doi.org/10.1128/jb.175.10.2943-2951.1993.

France, J., and J. Dijkstra. 2005. Volatile fatty acid production. Pages 157-176 in Quantitative Aspects of Ruminant Digestion and Metabolism, 2nd ed. J. Dijkstra, J. M. Forbes, and J. France, ed. CABI Publishing, Wallingford, UK.

Gasteiger, E., C. Hoogland, A. Gattiker, S. Duvaud, M. R. Wilkins, R. D. Appel, and A. Bairoch. 2005. Protein identification and analysis tools on the ExPASy Server BT. Pages 571-607 in the Proteolics Protocol Handbook. J. M. Walker, ed. Humana Press, Totowa, NJ. https://doi.org/10.1385/1-59259-890-0:571.

Georgelis, N., N. Nikolaidisa, and D. J. Cosgrove. 2014. Biochemical analysis of expansin-like proteins from microbes. Carbohydr. Polym. 100:17-23. https://doi.org/10.1016/j.carbpol.2013.04.094.

Georgelis, N., A. Tabuchi, N. Nikolaidis, and D. J. Cosgrove. 2011. Structure-function analysis of the bacterial expansin EXLX1. J. Biol. Chem. 286:16814-16823. https://doi.org/10.1074/jbc.M111 .225037 .

Goering, H. K., and P. J. Van Soest. 1970. Forage fiber analysis (Apparatus, Reagents, Procedures, and Some Applications). Agric. Handbook No. 379. ARS USDA, Washington, DC

Hanna, W. W., and L. E. Sollenberger. 2007. Tropical and subtropical grasses. Pages 245-256 in Forages: The Science of Grassland Agriculture. R. F. Barnes, C. J. Nelson, K. J. Moore, and M. Collins, ed. Blackwell Publishing, Ames, IA. 
Haque, M. A., K. M. Cho, D. N. Barman, M. K. Kim, and H. D. Yun. 2015. A potential cellulose microfibril swelling enzyme isolated from Bacillus sp. AY8 enhances cellulose hydrolysis. Process Biochem. 50:807-815. https://doi.org/10.1016/j.procbio.2015.02.003.

Jalilvand, G., N. E. Odongo, S. López, A. Naserian, R. Valizadeh, F. E. Shahrodi, E. Kebreab, and J. France. 2008. Effects of different levels of an enzyme mixture on in vitro gas production parameters of contrasting forages. Anim. Feed Sci. Technol. 146:289-301. https://doi.org/10.1016/j.anifeedsci.2008.01.007.

Kim, E. S., H. J. Lee, W. G. Bang, I. G. Choi, and K. H. Kim. 2009. Functional characterization of a bacterial expansin from Bacillus subtilis for enhanced enzymatic hydrolysis of cellulose. Biotechnol. Bioeng. 102:1342-1353. https://doi.org/10.1002/bit.22193.

Kritas, S. K., A. Govaris, G. Christodoulopoulos, and A. R. Burriel. 2006. Effect of Bacillus licheniformis and Bacillus subtilis supplementation of ewe's feed on sheep milk production and young lamb mortality. J. Vet. Med. A Physiol. Pathol. Clin. Med. 53:170-173. https://doi.org/10.1111/j.1439-0442.2006.00815.x.

Krueger, N. A., and A. T. Adesogan. 2008. Effects of different mixtures of fibrolytic enzymes on digestion and fermentation of bahiagrass hay. Anim. Feed Sci. Technol. 145:84-94. https://doi.org/10 .1016/j.anifeedsci.2007.05.041.

Kumar, R., S. Singh, and O. V. Singh. 2008. Bioconversion of lignocellulosic biomass: Biochemical and molecular perspectives. J. Ind. Microbiol. Biotechnol. 35:377-391. https://doi.org/10.1007/ s10295-008-0327-8.

Lenth, R. V. 2016. Least squares means: The R package lsmeans. J. Stat. Softw. 69:1-33. https://doi.org/10.18637/jss.v069.i01.

Lin, H., Q. Shen, J.-M. Zhan, Q. Wang, and Y.-H. Zhao. 2013. Evaluation of bacterial expansin EXLX1 as a cellulase synergist for the saccharification of lignocellulosic agro-industrial wastes. PLoS One 8:e75022. https://doi.org/10.1371/journal.pone.0075022.

Liu, X., Y. Ma, and M. Zhang. 2015. Research advances in expansins and expansion-like proteins involved in lignocellulose degradation. Biotechnol. Lett. 37:1541-1551. https://doi.org/10.1007/s10529 $-015-1842-0$.

Lou, J., K. A. Dawson, and H. J. Strobel. 1996. Role of phosphorolytic cleavage in cellobiose and cellodextrin metabolism by the ruminal bacterium Prevotella ruminicola. Appl. Environ. Microbiol. 62:1770-1773.

McQueen-Mason, S. J., and D. J. Cosgrove. 1995. Expansin mode of action on cell walls (analysis of wall hydrolysis, stress relaxation, and binding). Plant Physiol. 107:87-100. https://doi.org/10.1104/ pp.107.1.87.

Miller, G. L. 1959. Use of dinitrosalicylic acid reagent for determination of reducing sugar. Anal. Chem. 31:426-428.

Miron, J., D. Ben-Ghedalia, and M. Morrison. 2001. Invited review: Adhesion mechanisms of rumen cellulolytic bacteria. J. Dairy Sci. 84:1294-1309. https://doi.org/10.3168/jds.S0022-0302(01)70159 -2 .

Muck, R. E., and J. T. Dickerson. 1988. Storage temperature effects on proteolysis in alfalfa silage. Trans. ASAE 31:1005-1009.

Noel, R. J., and L. G. Hambleton. 1976. Collaborative study of a semiautomated method for the determination of crude protein in animal feeds. J. Assoc. Off. Anal. Chem. 59:134-140.

NRC. 2001. Nutrient Requirements of Dairy Cattle. 7th ed. National Academies Press, Washington, DC.

Oganesyan, N., I. Ankoudinova, S. Kim, and R. Kim. 2007. Effect of osmotic stress and heat shock in recombinant protein overexpression and crystallization. Protein Expr. Purif. 52:280-285. https:// doi.org/10.1016/j.pep.2006.09.015.

Olarte-Lozano, M., M. A. Mendoza-Nunez, N. Pastor, L. Segovia, J. Folch-Mallol, and C. Martinez-Anaya. 2014. PcExl1 a novel acid expansin-like protein from the plant pathogen Pectobacterium carotovorum, binds cell walls differently to BsEXLX1. PLoS One 9:e95638. https://doi.org/10.1371/journal.pone.0095638.

Orłowski,, A., L. Artzi, P. A. Cazade, M. Gunnoo, E. A. Bayer, and D. Thompson. 2018. On the distinct binding modes of expansin and carbohydrate-binding module proteins on crystalline and nanofibrous cellulose: Implications for cellulose degradation by designer cellulosomes. Phys. Chem. Chem. Phys. 20:8278-8293. https://doi .org/10.1039/c7cp07764e.

Pagliai, F. A., C. F. Gonzalez, and G. L. Lorca. 2015. Identification of a ligand binding pocket in LdtR from Liberibacter asiaticus. Front. Microbiol. 6:1314. https://doi.org/10.3389/fmicb.2015.01314.

Peters, A., U. Meyer, and S. Dänicke. 2015. Effect of exogenous fibrolytic enzymes on performance and blood profile in early and midlactation Holstein cows. Anim. Nutr. 1:229-238. https://doi.org/ 10.1016/j.aninu.2015.09.001.

Phakachoed, N., W. Suksombat, D. Colombatto, and K. A. Beauchemin. 2013. Use of fibrolytic enzymes additives to enhance in vitro ruminal fermentation of corn silage. Livest. Sci. 157:100-112. https://doi.org/10.1016/j.livsci.2013.06.020.

Pinheiro, J., D. Bates, S. DebRoy, D. Sarkar, and R Core Team. 2009. NLME: Linear and nonlinear mixed effects models. $\mathrm{R}$ package version 3. 1-137. https://CRAN.R-project.org/package=nlme.

Rey, M. W., P. Ramaiya, B. A. Nelson, S. D. Brody-Karpin, E. J. Zaretsky, M. Tang, P. Olsen, M. Rasmussen, J. Andersen, P. Jorgensen, T. Larsen, A. Soroki, A. Bolotin, A. Lapidus, N. Galleron, S. Ehrlich, and R. Berka. 2004. Complete genome sequence of the industrial bacterium Bacillus licheniformis and comparisons with closely related Bacillus species. Gen. Biol. 5: R77.1-R77. https:// doi.org/10.1186/gb-2004-5-10-r77.

Romero, J. J., E. G. Macias, Z. X. Ma, R. M. Martins, C. R. Staples, K. A. Beauchemin, and A. T. Adesogan. 2016. Improving the performance of dairy cattle with a xylanase-rich exogenous enzyme preparation. J. Dairy Sci. 99:3486-3496. https://doi.org/10.3168/ jds.2015-10082.

Romero, J. J., M. A. Zarate, K. G. Arriola, C. F. Gonzalez, C. SilvaSanchez, C. R. Staples, and A. T. Adesogan. 2015. Screening exogenous fibrolytic enzyme preparations for improved in vitro digestibility of bermudagrass haylage. J. Dairy Sci. 98:2555-2567. https: //doi.org/10.3168/jds.2014-8059.

Rosano, G. L., and E. A. Ceccarelli. 2014. Recombinant protein expression in Escherichia coli: Advances and challenges. Front. Microbiol. 5:172. https://doi.org/10.3389/fmicb.2014.00172.

Russell, J. B. 2002. Predominant ruminal bacteria and archaea. Pages 18-22 in Rumen Microbiology and Its Role in Ruminant Nutrition. J. B. Russell, ed. Cornell University, Ithaca, NY.

Sambrook, J., E. F. Fritsch, and T. Maniatis. 1989. Molecular Cloning: A Laboratory Manual. 4th ed. Cold Spring Harbor Lab. Press, New York, NY.

Seo, J. K., T. S. Park, I. H. Kwon, M. Y. Piao, C. H. Lee, and J. K. Ha. 2013. Characterization of cellulolytic and xylanolytic enzymes of Bacillus licheniformis JK7 isolated from the rumen of a native Korean goat. Asian-Australas. J. Anim. Sci. 26:50-58. https://doi .org/10.5713/ajas.2012.12506.

Shi, Y., and P. J. Weimer. 1992. Response surface analysis of the effects of $\mathrm{pH}$ and dilution rate on Ruminococcus flavefaciens $\mathrm{FD}-1$ in cellulose-fed continuous culture. Appl. Environ. Microbiol. $58: 2583-2591$

Silveira, R. L., and M. S. Skaf. 2016. Molecular dynamics of the $B a-$ cillus subtilis expansin EXLX1: Interaction with substrates and structural basis of the lack of activity of mutants. Phys. Chem. Chem. Phys. 18:3510-3521. https://doi.org/10.1039/c5cp06674c.

Singh, A., V. Upadhyay, A. K. Upadhyay, S. M. Singh, and A. K. Panda. 2015. Protein recovery from inclusion bodies of Escherichia coli using mild solubilization process. Microb. Cell Fact. 14:41. https://doi.org/10.1186/s12934-015-0222-8.

Tatusov, R. L., M. Y. Galperin, D. A. Natale, and E. V. Koonin. 2000 The COG database: A tool for genome-scale analysis of protein functions and evolution. Nucleic Acids Res. 28:33-36.

Tovar-Herrera, O. E., R. A. Batista-García, M. D. R. Sánchez-Carbente, M. M. Iracheta-Cárdenas, K. Arévalo-Niño, and J. L. FolchMallol. 2015. A novel expansin protein from the white-rot fungus Schizophyllum commune. PLoS One 10:e0122296. https://doi.org/ 10.1371/journal.pone.0122296.

Van Gylswyk, N. O., and J. J. T. K. Van der Toorn. 1985. Eubacterium uniforme sp. nov. Eubacterium xylanophilum sp. nov., fiberdigesting bacteria from the rumina of sheep fed corn stover. Int 
J. Syst. Evol. Microbiol. 35:323-326. https://doi.org/10.1099/ 00207713-35-3-323.

Van Soest, P. J., J. B. Robertson, and B. A. Lewis. 1991. Methods for dietary fiber, neutral detergent fiber and non-starch polysaccharides in relation to animal nutrition. J. Dairy Sci. 74:3583-3597. https://doi.org/10.3168/jds.S0022-0302(91)78551-2.

Wang, W. C., C. Liu, Y. Y. Ma, X. W. Liu, K. Zhang, and M. H. Zhang. 2014. Improved production of two expansin-like proteins in Pichia pastoris and investigation of their functional properties. Biochem. Eng. J. 84:16-27. https://doi.org/10.1016/j.bej.2013.12 .018 .

Warner, C. D., G. Camci-Unal, N. L. B. Pohl, C. Ford, and P. J. Reilly. 2013. Substrate binding by the catalytic domain and carbohydrate binding module of Ruminococcus flavefaciens fd- 1 xylo- glucanase/endoglucanase. Ind. Eng. Chem. Res. 52:30-36. https:/ /doi.org/10.1021/ie202988a

Wood, T. M., and K. M. Bhat. 1988. Methods for measuring cellulase activities. Pages 87-112 in Methods in Enzymology. W. A. Wood, and S. T. Kellogg, ed. Vol. 160. Academic Press. London, UK.

Yennawar, N. H., L. C. Li, D. M. Dudzinski, A. Tabuchi, and D. J. Cosgrove. 2006. Crystal structure and activities of EXPB1 (Zea M 1), a beta-expansin and group-1 pollen allergen from maize. Proc. Natl. Acad. Sci. USA 103:14664-14671. https://doi.org/10.1073/ pnas.0605979103.

Zhao, X., L. Zhang, and D. Liu. 2012. Biomass recalcitrance. Part I: the chemical compositions and physical structures affecting the enzymatic hydrolysis of lignocellulose. Biofuels Bioprod. Biorefin. 6:465-482. https://doi.org/10.1002/bbb.1331. 


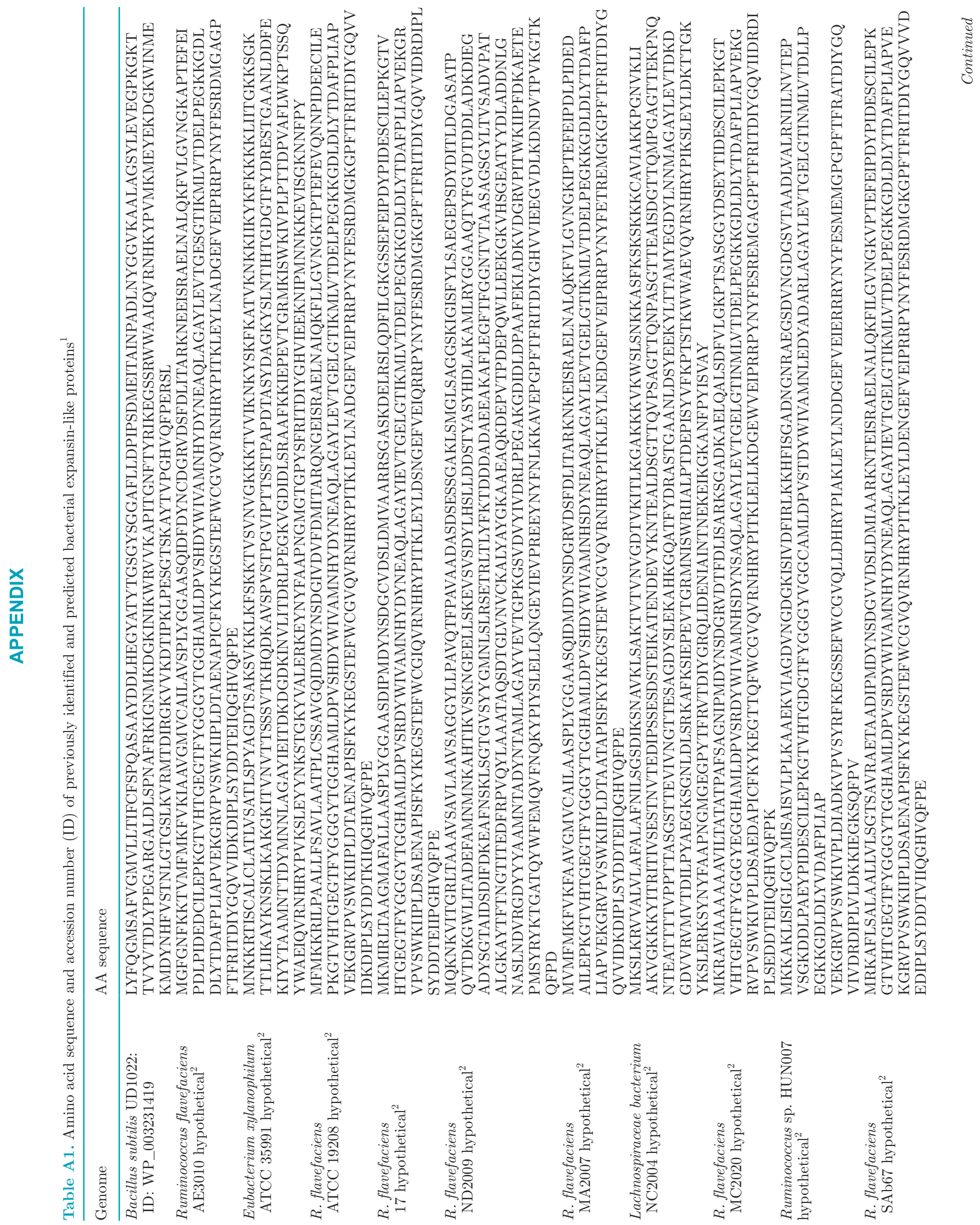


BACTERIAL EXPANSIN-LIKE PROTEINS AND FIBROLYTIC ENZYMES

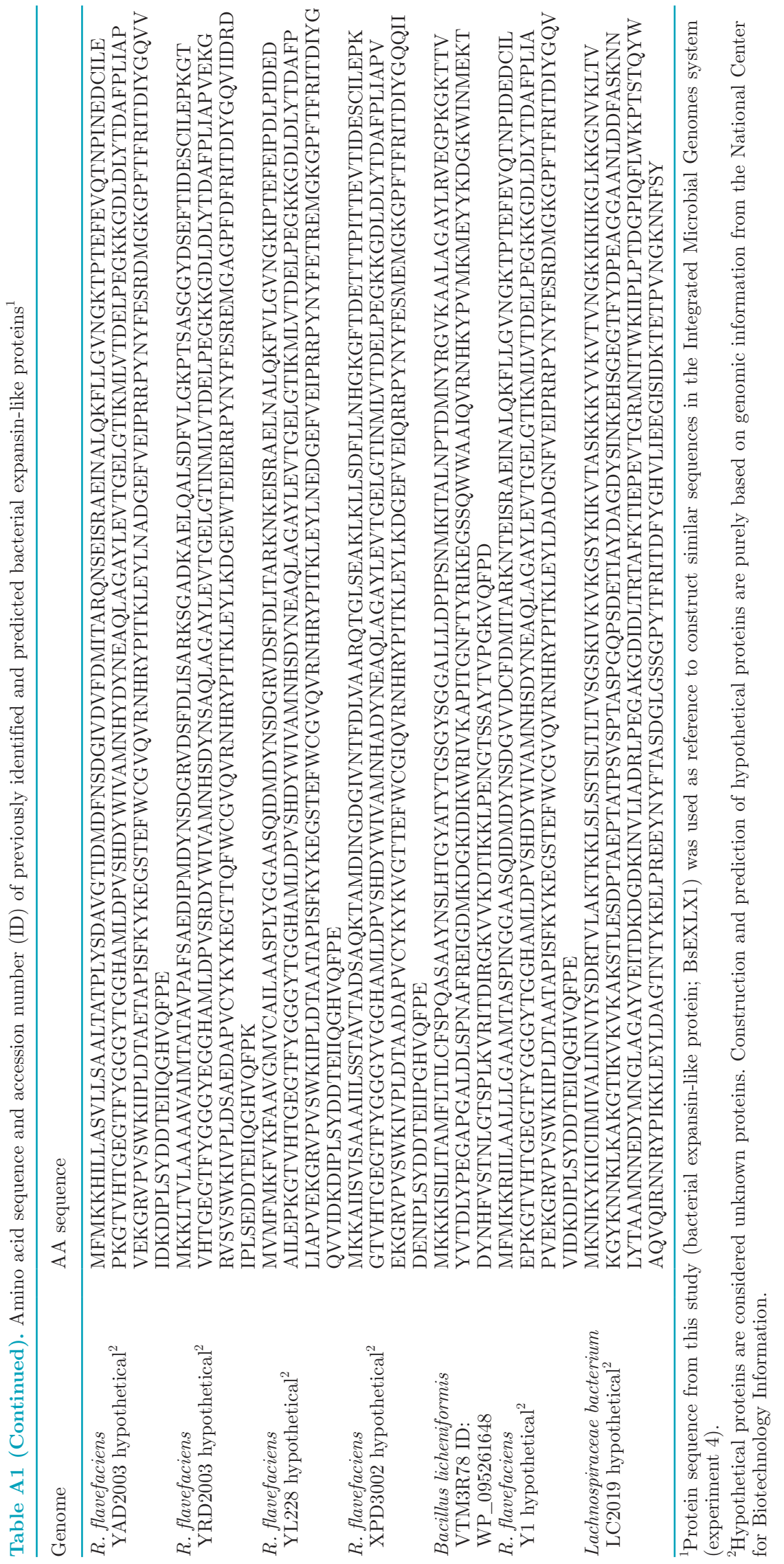

Journal of Dairy Science Vol. 96 No. 00000, 2013 